\title{
The Autobiographical Dimension of Brainy Books
}

\section{Arnaud Schmitt}

University of Bordeaux

\section{ABSTRACT IN ENGLISH}

This article purports to explore the autobiographical dimension of a recent publishing phenomenon, brainy books. It's my contention that these books display a constant dialectic tension between their source (academic research) and their target (non-academic readers), and one way of reconciling both sides consists in resorting to rhetorical strategies in order to make their research more accessible. One of these strategies is openly autobiographical. Through two case studies-Daniel Kahneman's Thinking, Fast and Slow (2011) and Paul Dolan's Happiness by Design (2014) - I study the various functions of this autobiographical dimension: perlocutionary, contextualizing, illustrative and finally autobiographical beyond functionality. It's my overall aim to demonstrate that the authors' choice to include personal anecdotes or even confessions in books primarily meant to spread knowledge to a larger audience makes brainy books a fascinating subject for life writing studies.

Keywords: brainy books, functional autobiography, anecdotes and confessions, scientific autobiography

\section{RÉSUMÉ EN FRANÇAIS}

Cet article se propose d'explorer la dimension autobiographique d'un phénomène éditorial récent, les ouvrages exigeants et parfois largement lus de vulgarisation scientifique (en anglais, les brainy books), et la façon dont ces livres affichent une tension dialectique constante entre leur source (la recherche universitaire) et leur cible (un lectorat non-universitaire). Une manière de réconcilier ces deux pôles consiste à avoir recours à des stratégies rhétoriques particulières afin de rendre cette recherche plus accessible. L’une de ces stratégies 
est de faire appel à l'autobiographie. À travers deux études de cas-Thinking, Fast and Slow de Daniel Kahneman (2011) et Happiness by Design de Paul Dolan (2014) — nous allons étudier les diverses fonctions de cette dimension autobiographique: perlocutoire, illustrative, contextualisante et aussi parfois tout simplement autobiographique, sans raison apparente. Je vais m'efforcer dans cet article de démontrer que le choix de ces auteurs d'inclure des anecdotes personnelles, voire des confessions, dans des ouvrages destinés en premier lieu à diffuser une connaissance auprès d'un public a priori non initié fait de ce type de livres un sujet d'étude fascinant pour les études autobiographiques.

Mots-clés: vulgarisation scientifique, autobiographie fonctionnelle, anecdotes et confessions, autobiographie scientifique

Brainy books are a recent phenomenon, even though they already existed before their rebranding under various guises, 'smart nonfiction' being one of them. Actually, it would be more accurate to claim that they existed without officially existing, be it as a category or, even less, as a genre. Brainy books allegedly stem from a more ancient and wider practice, commonly known as scientific popularization or vulgarization and seen as commercial offshoots of research led within universities. But contrary to the latter, brainy books have come to embody a respectable form of popularization and, in some cases, a profitable one. As we will see, they have also contributed to developing rhetorical tools of their own.

As a matter of fact, the term in itself is almost accidental, the result of bookshop branding rather than theoretical analysis. A perfect example of this fragile, serendipitous existence is an article published in Time in 2015 entitled 'Brilliant and Brainy Books to Take to the Beach This Summer'. Paradoxically enough, the term is used only in the title and not once in the article; furthermore, what it precisely refers to is never explained or contextualized even though at the time, it was only a budding phenomenon. The same can be said of online reviews such as S. Zainab Williams's very short piece 'On the Rise of Brainy Books, and the Best Brainy Books of This Decade: Critical Linking' which submits the following definition: "long-tail" nonfiction titles, often works on politics, economics, history or medicine that attempted to synthesise or challenge received thinking on the subject'.

It seems that originally, the designation was meant to refer to books related to neurosciences. There's even a non-fiction children's book written by Lorna Hendry entitled The Brainy Book (2015) supposed to explain to young readers the innerworkings of the brain. Another, much older and isolated example can be found in the title of a book review published in 1962 in a scholarly journal, Contemporary Psychology. In this short text, in the same way as, for instance, the Time article mentioned above, Galambos and Sheer use a classification-'A Big Brawny Brainy Book 
from Texas'-that is never clarified and, as in Hendry's case, the term pertains to brain research (more specifically, electrical brain simulation). But nowadays, if you enter, say, any Waterstones in the UK, you are very likely to find in the nonfiction department a small 'brainy book section' comprised of publications covering a wide range of topics far from being limited to 'hard science'. And yet, owing to the runaway success of some, mostly very recent titles, brainy books have become, almost out of the blue, a publishing force to be reckoned with, and also a new form of sharing one's research with a non-academic readership. A recent article published in The Observer entitled 'How the "Brainy" Book Became a Publishing Phenomenon' delves into this new editorial fad, while putting it into perspective as it essentially revolves around the success of a few titles, such as Yuval Noah Harari's powerhouse Sapiens: 'This is a story about a book that just kept selling, catching publishers, booksellers and even its author off guard. In seeking to understand the reasons for the book's unusually protracted shelf life, we uncover important messages about our moment in history, about the still-vital place of reading in our culture, and about the changing face of publishing' (Preston). The article expounds on the underlying reasons for this unexpected success, the first being 'a surge in the popularity of intelligent, challenging nonfiction, often books that are several years old' dealing with 'politics, economics, history or medicine' and intending to 'synthesise or challenge received thinking on the subject'. These books also often fill a hole left gaping by other sources of information and knowledge, and Preston's article in The Observer rightfully notes that 'great nonfiction offers us levels of detail, breadth of scope and depth of engagement that we simply don't get from other media', going as far as claiming that ' $[\mathrm{t}]$ hese are serious times and they demand serious, intelligent and challenging books'. Most importantly, these 'intelligent and challenging' books are written by academics whose research is normally inaccessible to most readers, which means that even though they're not as demanding as articles published in academic journals, brainy books are still 'written from a position of authentic authority' (Preston). Their main appeal arguably stems from this mix of accessibility and intellectual legitimacy. As we'll see later, the narrative skills of their authors underpin this accessibility.

The trade publication The Bookseller first noted this "dramatic shift [...] in the non-fiction market with "more intelligent" titles on the rise, partially the result of the continuing wane of the celebrity market' and the emergence of what it called the 'brainy backlist' ("Brainy Backlist" Helps Boost Non-Fiction Market'). The 'shift' is then described as moving away from easy and frowned-upon-but also often best-selling-reads to much more sophisticated texts displaying complex arguments and theoretical claims. Actually, the shift isn't so much a question of intellectual 
requirements as a generic difference, between autobiography-informed texts and essayistic, scientific ones. This is the main argument of this article that brainy books display a non-negligible level of self-narration, but this will be developed once this new category has been thoroughly introduced and defined.

Thus, the shift The Bookseller focused on is commercial (from one bestselling category to a new one) as they study "the "smart non-fiction" space that has become such a hot commodity' (Tivnan). When Tom Tivnan writes that 'science and history' have suddenly become 'subjects that are having a moment in the publishing world', he is of course referring to a commercial moment. But, as I just pointed out, the difference between celebrity memoirs and brainy books is fundamentally generic. I also think that as regards brainy books, readers who, impulsively or not, decide to pick up a book, purchase it and actually read it obviously have an altogether different horizon of expectations, one that doesn't comprise other genres or other reading options, but the original research of the author, its level of accessibility and the hope that the text they are about to read is both faithful to this research as it was developed in varied scientific journals and much more comprehensible. As Lesley Graham eloquently underlined in her excellent article on scientific autobiographies, '[t]hey may be flattered by the illusion of a privileged one-to-one encounter with scientific and medical authority or seduced by the promise of a confidential, conversational tone; the prospect of entertaining anecdotes and inside information, the taking off of the white coat, but the reassurance that it is hanging on a hook somewhere there in the background'.

In a similar fashion to scientific autobiographies, brainy books display a constant dialectic tension between their source (academic research) and their target (non-academic readers). They must develop strategies, not to alleviate these tensions but to turn them into attractive features. This dialectic defines to a certain extent the overall approach of brainy books' authors who are 'experts [...] exploring interesting fields of study, but [who] can also write for the general reader and have a track record of engaging broader audiences' (Tivnan). Indeed, stating that these authors are a form of 'interface between the intellectual and the commercial' is both an essential and occasionally an incomplete assessment. Being an 'interface' corresponds to an authorial stance that implies a particular position with regard to one's research, one's will to spread this research beyond academia and above all the tools at one's disposal to do so. As made explicit above, Sapiens's success was not planned, and was certainly not part of a marketing strategy laid out by cunning publishers. As a matter of fact, this success was almost an accident that happened mostly thanks to the dogged determination of a bookstore chain. Kiera O'Brien, 
charts and data editor at The Bookseller, describes how this determination impacted the book's runaway success: 'There's a lot of recent historical nonfiction that has been given a bump by Waterstones, particularly their book of the month promotions. And it's often stuff from tiny publishers which, given that initial boost, can then establish itself in the charts and stay there for a very long time' (Preston). And yet, the very content of the book made it possible to draw a large audience that, based on the book's and its author's current popularity, was waiting for such a text.

There might be contextual, extraneous elements accounting for the very positive reception of smarter nonfiction and even what seems to be a thirst for brainy books, but it's the internal elements we are now going to turn our attention to. The accessibility of brainy books, their unexpected 'commerciality', is the result of the aforementioned tension between two means of disseminating the results of one's research. But these tensions don't necessarily amount to a form of compromise. As Preston underlined in The Observer, the brainy backlist shouldn't be equated with a watereddown version of someone's research: 'We're seeing these big sweeping narratives that people are reaching for as a way of making sense of this unstable world, and on the other hand you have a new generation of activist-writers who are telling stories of gender, politics or race and doing it on their own terms, very much going against what went before. These are bold books, quite radical, really exciting and tend to be younger writers writing for younger readers'. (Preston) Reni Eddo-Lodge's Why I'm No Longer Talking to White People about Race, among one of The Observer's best brainy books of the decade (Killian Fox and Poppy Noor), certainly is a perfect illustration of these 'radical, really exciting' books. But Reni Eddo-Lodge is a journalist, not an academic, which means that an essay can be one of her primary forms of expression. This isn't the case of the two examples I'll present in the second part of this article, books written by academics who had to find a way of exporting their research into a new rhetorical vessel.

\section{THE RHETORIC OF BRAINY BOOKS}

So far, the research devoted to brainy books is very limited, to say the least, especially because as a category, it's hardly a recognized one, and when it is, people still don't know what to make of it in terms of academic status (Is it still research? Should it be the subject of any research project?). Publications can be found on the-slightly peripheral as far as the thematic range of this article is concerned-topics of narrative or rhetorical strategies implemented in scientific papers (see for instance Woolgar 1980 
or, of course, Myers 1990, 1991), on the parallels between the referential intentions of works of scientific popularization and autobiographies (Jurdant 2018) or on scientific autobiographies (Graham 2004). Among all these resources, only Graham's article comes close to being relevant to the study of brainy books. More precisely, just one group in her brief typology of scientific autobiographies can be more or less closely related to brainy books: 'a memoir of a specific period and a specific discovery, that of the helical structure of DNA, undoubtedly one of the canonical works of this genre [...]'. But the text Graham refers to, Watson's The Double Helix. A Personal Account of the Discovery of the Structure of DNA, serves a different purpose than the texts we are going to study below: it presents the reader with the story of a discovery whereas most brainy books try to articulate ideas generated through research, admittedly resorting to narrative tools and micro-stories but not to an overarching narrative, as it is usually done in a memoir.

Eventually, Susheela Abraham Varghese and Sunita Anne Abraham's article 'Book-Length Scholarly Essays as a Hybrid Genre in Science' represents one of the only academic resources dedicated to the phenomenon of brainy books, even though not once do they mention the term in their long article. Their research focuses on 'Book-Length Scholarly Essays' a category whose contours are not as all-encompassing as the ones described in The Observer's article but that still matches most of the features put forward in Preston's analysis. However, Reni Eddo-Lodge's book wouldn't fit into their framework as they only consider texts published by academics and based on pre-existing research.

They start by addressing one of the key issues regarding these long essays: their status. Indeed, in a world in which the journal article still represents in terms of publication 'the pinnacle of knowledge creation', publishing a book 'in the sciences has traditionally been viewed as a "low status activity"' best left to "non-scientists, failed scientists or ex-scientists [...]', a way to write 'about science rather than in science' (Varghese et al., 202). Book publishing often amounts to 'knowledge dissemination to nonspecialist audiences [...] too easily conflated with popularizations' (203). This academic scorn for books in the so-called hard sciences doesn't extend to social sciences and the humanities for which publishing a book on one's research still represents an asset on one's résumé, but of course only if one publishes within an academic context (i.e. if one's book is published by university presses or major outlets such as Routledge). Indeed, if one's book is published by a more traditional (and commercial) publisher for non-academic readers, the description of one's research, if not the results, will have to be drastically altered (i.e. simplified). However, things are not always so unilaterally rationalized. As the success of books 
such as Daniel Kahneman's Thinking, Fast and Slow (one of our two case studies) or, to take a purely scientific example, Carlo Rovelli's Seven Brief Lessons in Physics - both also listed by The Observer among the best brainy books of the decade-indicates, academic scorn can be turned into a form of recognition when the success met by these titles becomes so imperious: 'Particular volumes written by individual writers have been publicly acclaimed through best-seller lists such as the New York Times and awards such as the Pulitzer. Not only do these authors receive book royalties and honoraria for guest lectures given about these works, but some of them have also gone on to very packed public schedules including interviews on talk shows and book signings' (203). This sudden form of recognition, even among academic circles, shouldn't be brushed aside as in the long term it might have a direct influence on the very content of these brainy books but, more importantly, on the way one promotes, or simply spreads one's research. Furthermore, Varghese and Abraham also perceive these books as distinct from watered-down version of 'normal' research publications and insist that they shouldn't be 'conflated with popularizations' (203), although they obviously imply a form of simplification (in other words, adaptation to a non-specialist readership).

But the most important part about Varghese and Abraham's article is, by means of their use of samples, their rhetorical analysis of 'booklength scholarly essays'. Their endeavor is original for two reasons: first, as mentioned earlier, very little attention has been paid to the adaptation of scientific research to non-academic readers as "current work on popularizations has focused on relatively short accommodations of fewer than 10 pages written by nonresearchers'. Indeed, '[n] one of these studies has investigated the book-length scholarly essays written by practicing researchers' that is the topic of their own research. Second, they decided not to focus exclusively on hard sciences but instead 'investigate this genre across disciplines to better explore a phenomenon that appears to be affecting many scientific disciplines' (206).

The first rhetorical aspect they took into account is not textual, but contextual even if it has a direct bearing on the former: 'Unlike more conventional research genres, where the roles of specialist author and audience are taken for granted, these authors explicitly build a dialogue with their readers' (208). And it's the form of dialogue that, as we'll see later, makes brainy books potential research subjects for autobiographical studies. I will jump directly to the most important parts of Varghese and Abraham's analysis and conclusions, as their excellent article is based on a thorough, quantitative methodology that enhances the specificity of brainy books, even if, again, they don't use this term. From a purely rhetorical point of view, and rhetorical should be understood here according 
to Phelan's understanding of narrative as rhetoric ('the telling of a story by someone to someone on some occasion for some purpose', $8^{1}$ ), this genre is characterized by:

- 'prefatory comments in these volumes and personal communication from some of the authors' (213)

- 'a more reader-friendly style' (214)

- 'a combination of anecdotes-what Pinker (personal communication, December 20, 2002) calls hooks-and seemingly absurd questions that entice the reader to read on by piquing their interest about compelling physical and/or social phenomena' (215); and of course, '[b]y posing questions, these authors invite their audience to actively participate in a mutual exploration of a subject' (217)

- occasionally, an 'interesting yarn' (216)

- 'the rhetorical intention of some of these academics to pursue a synthesis and reformulation of knowledge that crosses disciplinary boundaries' (218)

The authors conclude by saying that these books definitely don't conform to traditional scientific criteria, but resemble 'another academic genre-the genre of philosophic essays described in detail in Geisler (1994)' (224). It is my claim that, if brainy books can arguably be read as 'philosophic essays', Varghese and Abraham have underplayed the personal element in these essays, even though it is the backbone of all the features listed above. Not only are they personal-as opposed to the 'objective', neutral style still recommended in academic publications-, they are autobiographical as I will try to demonstrate using Varghese and Abraham's research but taking it a step further.

\section{CASE STUDIES}

The two brainy books I've chosen to illustrate the essential autobiographical nature of this genre come from the same disciplinarian field, cognitive sciences. It's the one I'm most familiar with as I mostly read brainy books to perfect my knowledge of a field that's not the one in which in originally conducted my research, but to which I resort more and more as it has become essential tools in my analytic approach. The first example, Daniel Kahneman's Thinking, Fast and Slow (2011), is one of the best-selling brainy books of the decade, ranked third in The Observer's list mentioned above. The second one, Paul Dolan's Happiness by Design (2014) is not as famous as the first one-let's keep in mind that Kahneman was awarded 
the Nobel Prize in Economics in 2002-but was still widely reviewed (and includes a foreword by Kahneman himself).

Both books have many common features. The first one is their author's strategy: contrary to the more essayistic and journalistic nature of Reni Eddo-Lodge's book, Kahneman and Dolan's projects classically consist in finding a new audience for their research by altering the rhetorical means of presenting their results. One of these alterations is the inclusion of autobiographical elements. We'll now study these elements and their different functions, but it's important to stress that these functions often overlap.

\section{ADDRESSING THE READER}

Autobiography's main purpose is relational: 'As a genre, autobiography is characterized less by a set of formal elements than by a rhetorical setting in which a person places herself or himself within testimonial contexts [...]' (Gilmore 3). Because these 'formal elements' and 'rhetorical setting' fall under the more general rules of narrative (as a form of expression), Phelan's previously quoted famous definition of narrative as rhetoric should be added to Gilmore's introductory definition of autobiography. Traditional research's main purpose is definitely not to make knowledge accessible to readers beyond a restricted circle generally consisting of specialists of a particular field, but to present it as formally and rigorously as possible, mostly because the subjective (and, as a consequence, intersubjective) dimension is to be kept to a minimum.

For the authors of brainy books, the first adaptation requires to become authors (of communicational acts). In these two books, but also in many others, this relational function is filled by autobiography, but also sometimes simply by addressing more or less directly the reader. Kahneman starts his introduction in the following way: 'Every author, I suppose, has in mind a setting in which readers of his or her work could benefit from having read it. Mine is the proverbial office water-cooler, where opinions are shared and gossip is exchanged' (3). Dolan opens his own note to the reader with an even more direct address: 'I'd like to thank you for buying my book. It makes me happy, and I hope it will make you happy, too' (ix); 'As I'm sure you are only too well aware, managing other people's expectations of you is an important skill, and so I won't make promises to change your life; but I do hope to provide some insights into how you can change what you do' (xi). Kahneman and Dolan also employ the types of perlocutionary strategies described by Varghese and Abraham, that is to say asking direct questions to their readers, consequently 'invit[ing] their audience 
to actively participate in a mutual exploration of a subject'. Mostly, they ask questions to the reader or ask them to perform tasks so that they take part in some of the experiments that supported their research. This is both perlocutionary and inclusionary. The beginning of Thinking, Fast and Slow is a perfect example. Kahneman presents us with a picture (as he'll do several times throughout the book with various figures) and asks us to 'observe [our] mind in automatic mode' and 'glance at the image below'. Once we've done exactly that, he starts explaining to us what we've just been experimenting-'Your experience as you look at the woman's face seamlessly combines what we normally call seeing and intuitive thinking' (19) - and then gradually branches back to a more formal presentation of the research related to the experiment. These 'hooks' draw the reader's attention, engage her and above all concretize the research.

As for Dolan, the strategy is exactly similar. For instance, one of Happiness by Design's many preliminary parts aptly entitled 'A little warm-up' includes a grid listing 20 items that could potentially make us happy or happier. In this part, Dolan gives us the following assignment: 'Before we move ahead, I'd like you to look at the following list of twenty items that could potentially make you happier. From this list, what are the four items that would make you happiest?' (xiii). Thus, addressing the reader openly breaks most academic rules and places their research into a new narrative and communicational dimension. It's also a way of influencing the form of response they want for their work. But addressing, even engaging the reader doesn't amount to autobiography per se, whereas some of Kahneman and Dolan's other strategies to appeal to a large readership do.

\section{CONTEXTUALIZING}

First, the emphasis on context isn't particularly surprising for two researchers who come from a field, cognitive sciences, that often consider context as a defining element of human behavior: 'So any attempts to understand human behavior and happiness must properly account for the effects of external context as well as internal cognition-for "contextology" as well as psychology' (Dolan xx). But switching to autobiographical mode to contextualize one's research also allows to better justify the purpose of one's work, to enhance its practicality (more exactly, a practicality understood by a non-specialist audience as the results obtained by research projects conducted within the field of natural sciences, psychology or engineering for instance can indeed be quite practical even though one would require a certain level of knowledge to grasp the nature and scope of this practicality) - to be understood as referring to the praxis of research and 
not particularly here to its possible applications-and above all to situate a concept within a real-life environment.

This contextualizing trend is also a way of giving flesh to-sometimes very abstract-ideas and, in parallel, to narrate an experience that generally remains untold (at least autobiographically, David Lodge took care of tapping into its most preposterous aspects in his fiction): the life of a researcher and of an academic. However Lesley Graham demonstrates in her article that scientific autobiographies (which sometimes turn out to be simply autobiographies by scientists) are quite common and started many decades ago to unveil what goes on in a lab or in the head of a scientist, even more so as 'a careful reading of autobiographical documents-their narrative arguments, their inclusions and omissions, their use of language - can teach us a great deal about the ways and the contexts in which scientific knowledge is created [...]'. But even though there are similitudes, such as 'a concern with the accessibility of science' that according to Graham tie 'these scientists' autobiographies together', it is seminal here to stress the difference between a scientific autobiography, focusing on the life and work of a scientist, and a brainy book, focusing on the research of the author and, only secondarily, on her life. This difference is measured primarily by the amount of autobiographical content which remains in the case of brainy books limited but essential.

Both Dolan and Kahneman appear keen to disclose the usually hidden parts of a project, what contributes to a paper but doesn't appear in it. For instance, quite significantly, Kahneman compares implementing a particular experiment and preparing the related research paper by interpreting the results to a 'story' (9) and reveals the seminal subjective process behind any so-called objective research. While describing the reasons why they chose a particular type of participant in an experiment over another one, he writes: 'Of course, we did not choose demonstrations over standard experiments because we wanted to influence philosophers and economists. We preferred demonstrations because they were more fun, and we were lucky in our choice of method as well as in many other ways. A recurrent theme of this books is that luck plays a large role in very story of success $[\ldots]$. Our story was no exception' (9). To a certain extent, this behind-the-scene approach is meant to, but also contributes to making research-a practice unknown to the vast majority of the populationmore personal: personal in terms of recounting a person's experience but also of making it relatable to the reader. To use Pinker's metaphor again, it is an autobiographical hook. Similarly to Kahneman, Dolan does not hesitate to give his readers a glimpse of the context of his own research. One example among many: 'I first thought about spillover effects when I was working with the UK government to consider behavior change policies. I 
was presented with some evidence that enlarging the front compartment of a supermarket cart leads to increased sales of fruit and vegetables. The policy wonk that told me was very excited. I was excited to know if these increased sales led to increased consumption of fruit and veg' (57). It is also important to note that these contextualizing sections often contain a humorous note, a desacralizing intention aimed at contrasting with the more official and sophisticated ideas presented throughout the book. From a purely narrative point of view, a structural one more precisely, they can be seen as 'softer parts' leading up to intellectual peaks which will be followed by a decompressing, descending illustrative part, a redefinition of the concept enriched by the illustration in other words. By and large, most chapters of both books are built around this pattern, one that in a way is reminiscent of, but not similar to Vladimir Propp's own crisis-oriented, also ascending and descending, basic narrative pattern. It's sometimes difficult to differentiate between the openly illustrative parts we'll focus on below and the contextualizing ones simply meant to show the 'daily grind' as shown by the following example drawn from Kahneman's chapter dealing with anchoring and priming effects:

When Amos and I debated anchoring, I agreed that adjustment sometimes occurs, but I was uneasy. [...] Amos was more conservative than I was about hunches, and he correctly pointed out that appealing to suggestion did not help us understand anchoring [...]. I had to agree that he was right [...]. We conducted many inconclusive experiments in an effort to understand anchoring, but we failed and eventually gave up the idea of writing more about it. The puzzle that defeated us is now solved, because the concept of suggestion is no longer obscure [...]. (122)

This technique is similar to a painter showing the various sketches leading to the final painting, while also providing information about her process of creation. It also provides a different narrative, one usually kept out of research articles: research as failure, as groping along, research as stumbling along toward elusive and shifty certainties. And it logically also presents the narrative of the people who walk this strenuous path.

Indeed, contextualizing one's research amounts to contextualizing an important part of one's life; these contextualizing parts-not to be mistaken with the more formal ones devoted to describing the scientific context in which Dolan and Kahneman operate-reveal personal traits of their authors, a subjective-and still very restricted-window unbefitting traditional research. It serves a relational purpose as already pointed out, but also, as all autobiographical ventures, a narcissistic one. Narcissism shouldn't be understood here in any derogatory way but simply refers to a driving psychologic force that is enhanced by exposure to 
others, especially through a work of art or some artefact highly valued by society. This exposure gives way to a form of 'narcissistic comfort' ('réconfort narcissique', Rousseau-Dujardin 247), a normal process as, according to French psychoanalyst Michel De M'Uzan, any form of artistic creation involves a 'narcissistic expansion' ('expansion narcissique', De M'Uzan 133). The inclusion of brainy books into the artistic field can be argued or debated, but they certainly imply a significant amount of self-exposure. The latter is at odds with academia's strong emphasis on a form of selfless writing. But Graham perfectly sums up this seeming contradiction: 'Paradoxically scientific autobiographers also write to assert their singularity. As regards the scientific community, their message often seems to be double: "I am one of them; a respected member of the tribe, but I'm not like them." Creative writing materialises that difference. In the words of Claude Bernard, "L'art, c'est moi; la science, c'est nous" (In Beer 1987: 39).'

\section{ILLUSTRATING}

Brainy books' accessibility also strongly relies on their illustrative dimension, their ability to show how their author's research stems from daily life and can be applied to everyday situations. In this regard too, Kahneman and Dolan resort to autobiography.

One of Thinking, Fast and Slow's main arguments is that our intuitions and any form of intuitive thinking, as strong and reliable as they sometimes appear to us, are often misleading, if not preposterous. On several occasions, Kahneman draws from his own experience to illustrate this point: 'Unfortunately, professionals' intuitions do not all arise from true expertise. Many years ago I visited the chief investment officer of a large financial firm, who told me that he had just invested some tens of millions of dollars in the stock of Ford Motor Company. When I asked how he had made that decision, he replied that he had recently attended an automobile show and had been impressed. "Boy, do they know how to make a car!" was his explanation' (12). This is one of the essential tropes, if not the main one, of brainy books: their ability to situate theoretical concepts within an environment familiar to readers. Paul Dolan doesn't hesitate to get even more personal than Daniel Kahneman when it comes to his illustrative strategies:

When others remember your happiness, they might not be as influenced by peak-end effects as you are. I am sure that Les [Dolan's wife] remembers how good my nights out with her were in our prechildren partying days better than I do, and I am equally convinced that I remember how good her 
nights out with me were better than she does. As much as I hate to admit it, she probably has a better memory for them than I do. Studies have shown that under timed conditions, women remember both more positive and more negative autobiographical life events than do men. (117)

You can notice here what I would call brainy books' typical contractingexpanding narrative movement: the author starts with a generalizing introduction to a particular concept, then zooms in on a specific example drawn from his own experience (or in other cases from someone else's) and zooms out in order to sharpen the initial definition of his concept. In the previous example, Dolan starts a part entitled 'Pay attention to the feedback of others' with an explanation of the benefits of perspective swapping and of the importance of monitoring one's expectations, then moves on to the illustrative autobiographical part quoted above to finish with a refined version of the concept that might still include shorter illustrative bits. In this particular instance, Dolan finishes up with a very short illustration: 'Recall my friend who works at MediaLand and who evaluates her job positively-in spite of the fact that it makes her miserable on a daily basis. I can see an experiencing self that is suffering perhaps more clearly that she can. Since reading a draft of this book, my friend has started looking for a new job' (119).

Of course, many of the autobiographical elements both books are peppered with serve an illustrative function-to make conceptual notions more accessible to a non-academic readership-but they also draw their author within the realm of self-representation. They don't at first sight seem to reveal much of the most private parts of the authors' lives but other parts do and in a way all these autobiographical parts, whatever their level of privacy and their functionality, are connected and end up forming a portrait of their author, not just as a researcher.

\section{AUTOBIOGRAPHY}

There are autobiographical passages in Thinking, Fast and Slow and Happiness by Design that seem to exceed their primary, illustrative function, or to provide us with personal information that are not limited to helping us figuring out what the author is writing about. In a way, including these parts is a choice, an ontological choice that makes brainy books, or at least certain brainy books perfect candidate for life writing studies. Let me start with a long and telling example extracted from Dolan's book:

Here's a confession that until recently I would have made only to my family and very close friends. I have a stammer (or stutter, if you prefer; they 
mean the same thing). It has probably been the single biggest blot on my landscape of happiness. It has been with me all my life and it has always affected me, despite my largely successful attempts to keep it hidden. My mother took me to see a speech therapist when I was about seven years old and I was told that I would grow out of it. My stammer was especially awful when I was a teenager. I couldn't say my name. [...] As any stammerer will tell you, its frequency and severity are variable and so it takes a lot of what I call 'attentional energy'. (xv)

You'll recognize the familiar pattern of condensation and expansion (last sentence), but this is not this passage's most striking aspect. As underscored by Varghese and Abraham, one of the main rhetorical buttresses of brainy books is the anecdote, that is to say a 'light', noncommittal form of life writing. As seen previously, the use of anecdotes serves an intersubjective as well as illustrative purpose. But Dolan's strategy here reaches a different autobiographical level as he switches to a different mode: the confession. This is a perfect indicator of brainy books' generic looseness, and also to a certain extent the narrative latitude, even freedom they grant to their authors-again as opposed to the more corseted form of research publications; it also reveals how dependent they are on autobiographical resources. Is resorting to confession in this context necessary? No. Does it enhance the intersubjective relation with the reader? Almost certainly. And by doing this, Dolan draws the reader further into his narrative and his concepts, accentuating the practical, 'real-life' aspect of his research.

Furthermore, as personal as this confession is, it's nothing to be ashamed of; stammering isn't Dolan's fault, he hasn't done anything wrong or harmed anyone. This is for instance radically different from some of the confessions one can find in more traditional autobiographies but because context is all-important, a confession is still at variance with the rest of the text in a brainy book. What matters here is Dolan's choice; he clearly could have done with a less revelatory episode-revelatory here is to be understood by 'revealing a deeper personal psychological layer that is usually kept out this type of books'-but chose to up the autobiographical ante for the reasons made explicit above that can be summed up thus: more 'risks', more impact. Of course, these confessions are also remarkable because they are scarce. Let's take another example also from Dolan's book before comparing the latter's confessions to Kahneman's. Discussing children's impact on their parents' happiness, Dolan switches to confessional mode:

\footnotetext{
'So when I first started thinking about having kids of my own about a decade ago, the happiness-informed decision could well have been to remain childless, right? Perhaps, but the data at that time were based
} 
largely on evaluations of life satisfaction and partly on experience of pleasure alone. [...] Armed with the strong intuition that having children could potentially make me happier by adding more purpose to my already pleasurable life [...] I decided to take the plunge and have kids. Les and I now have a daughter, Poppy, who is six, and a son, Stanley, who is five. They bring us a bit of pleasure, a lot of misery, and a massive dose of purpose' (11-12).

This is a lesser degree of confession compared to admitting to a personal flaw concealed to others for years, but this is still very personal as it refers directly to Dolan's family and his own experience as a parent. Of course, as it is always the case, the confessional bits and pieces are mixed with more purposeful parts, the author's presentation of his 'pleasurepurpose principle' concept. Consequently, it could be argued that the autobiographical content is never purpose-free, never intended to be merely autobiographical. But the counter-argument is imperious: every autobiography is purposeful. The first obvious function is to tell about oneself to someone else and from this original function, many others branch out. Using one's own life narrative to illustrate a particular set of ideas or notions still fits within the scope of life writing: first because the author could have illustrated his points by using others' experiences, as Dolan also does repeatedly, and second because a personal anecdote or even confession meant to clarify a concept is still an anecdote or a confession. Are concepts and autobiography intertwined? This seems to be the most probable interpretation, but there's also a form of balance that sometimes tips in favor of functionality but can also tip in favor of autobiography as in the case of Dolan's confession where the level of intimacy outstrips the purpose intended. This particular tension between brainy books' two rhetorical sides, functionality and autobiographical illustration, is the reason why they are, as already stated, a fascinating candidate for life writing studies.

Kahneman's own strategy is by and large more anecdote-oriented than confessional. As previously seen, he often takes a back seat in the micronarrative, the anecdote being first and foremost about someone else, the author being simply 'involved'. Thinking, Fast and Slow and Happiness by Design are dissimilar in length, the former is longer but so is Kahneman's career and the number of concepts exposed is logically higher in his work. In a way, Kahneman has less time for autobiographical digressions and he principally resorts to his life, as mentioned earlier, to contextualize his research and expound on his theoretical input. But like Dolan's strategy, there is a thin line between functional evocation and one that might be less tightly connected to any form of necessity and that simply gives way to self-narration. 
For instance, to illustrate one of the numerous cases of professional delusion and overconfidence, Kahneman offers the following memory: 'Many years ago, my wife and I were on vacation on Vancouver Island, looking for a place to stay. We found an attractive but deserted motel on a little-traveled road in the middle of a forest' (258). The fact of mentioning his wife logically arouses expectations of an intimate episode from his past but it however quite pragmatically veers back toward a theoretical point. And yet, other anecdotes are not as neutral as this one, such as his several evocations of his work for the Israeli Air Force: 'I had one of the most satisfying eureka experiences of my career while teaching flight instructors in the Israeli Air Force about the psychology of effective training. [...] This was a joyous moment of insight, when I saw in a new light a principle of statistics that I had been teaching for years' (175). 'Eureka experiences' could at first sight be equated with contextualizing his research but they vary in degrees of intimacy and some transcend their primary function and contribute to a more personal portrait of their author. These memories of working with the Israeli army, though essentially illustrative, culminate and retrospectively find an additional meaning in his account of this experience as he visited Israel several times when suicide bombings in buses were frequent, 'though of course quite rare in absolute terms', and despite the fact that Kahneman mostly travelled by car, his behavior was affected by the circumstances: 'I was ashamed of myself, because of course I knew better. [...] But my avoidance of buses was not motivated by a rational concern for survival. What drove me was the experience of the moment [...]. My experience illustrates how terrorism works and why it is so effective: it induces an availability cascade' (322). Functionality is here inextricably mixed with emotions (more subdued in Kahneman's case than in Dolan's but this is the point of autobiography, to reveal different personalities) and personal experience, and this mix demonstrates how an autobiographical account can enhance a conceptual demonstration. In a way, this extract illustrates what brainy books are at their best: autobiography-informed essays.

But what amounts to mere autobiography in Thinking, Fast and Slow, close to Dolan's confessions in a way, is Kahneman's countless evocations of his work with Amos Tversy and above all their friendship, starting early in the book by describing how they started working together ('He was brilliant, voluble, and charismatic. [...] There was never a dull moment when Amos was around. He was then thirty-two; I was thirtyfive', [5]), and then recurrently evoking their research together ('My collaboration with Amos in the early 1970s with a discussion of the claim that [...]', [112]; 'When Amos and I debated anchoring...' [122] ...). 
Actually, a host of paragraphs start in the following way: 'Amos and I...' (for instance, pages 10, 129, 169, 212, 316, 364). Indeed, in the final analysis, Kahneman's description of his research with Amos Tversy often feels like a testimony to one of the most seminal aspects of his life, whether personal or professional, and to what he eventually calls their 'story' (7): 'We developed a routine in which we spent much of our working days together, often on long walks. For the next fourteen years our collaboration was the focus of our lives, and the work we did together during those years was the best either of us did' (my emphasis, 6). Kahneman and Tversy's professional and personal relationship, 'shared mind that was superior to our individual minds' (10), is one of the most fascinating aspects, and doubtless one of the most personal features of this brainy book, because the 'thinking' analyzed in it might be alternatively 'fast and slow', but what Kahneman experienced during the collaboration/ friendship he describes at great length is an exceptional form of thinking with.

A narrative of collaboration would have fitted the overall purpose of research contextualization that's one of the common topoi of brainy books, but this is more than just a narrative of collaboration, it's one of a deep friendship and Tversy's death, mentioned repeatedly throughout Thinking, Fast and Slow, suffuses these parts with a lingering and moving sadness.

\section{CONCLUSION}

In Towards a 'Natural' Narratology, Monika Fludernik defined experientiality in narrative as 'the dynamic interrelation between the description of personal experience on the one hand (the setting-plus-incidence core of the narrative episode) and the evaluative and rememorative transformation of this experience in the storytelling process: tellability and point of the story dialectically constitute each other. The narrative is a narrative, not because it tells a story, but because the story that it tells is reportable and has been reinterpreted by the narrating I, the personal storyteller' (70). Based on what I've tried to demonstrate, the 'tellability' of brainy books stems from their autobiographical input. Quite pragmatically, the numerous anecdotes peppering these texts draw the reader in by triggering off identification processes since, apart from their being mostly renowned researchers, these authors' lives often resemble ours (or at least they make sure the chosen anecdotes give this impression). But as shown in the last part, limiting this autobiographical dimension to an illustrative function would lead to an oversight: a failure to notice that what separates research papers and brainy books 
is the presence of $I$. The former are we-narratives whereas the latter are I-narratives. Brainy books give their authors the opportunity to shift to autobiographical mode and grants them the opportunity to tell a large or at least larger audience about their lives, not only their professional one as made obvious by some of the passages quoted above. And autobiographical pleasure, the drive to tell others about ourselves is one of the driving rhetorical forces in our lives, structuring our daily communication acts.

Even though this article is meant as a stepping stone to a longer study taking into account more data and greater variations, I can confidently claim that the main trends I've explored here regarding the main rhetorical strategies implemented by Kahnman and Dolan can be found in many other books. To drive my point home, let me quote a few passages from Lisa Feldman Barrett's How Emotions Are Made, a brainy book offering a constructivist approach to the science of emotions. The first lines are quite eloquent as far as the author's autobiographical intent is concerned: 'Once upon a time, in the 1980s, I thought I would be a clinical psychologist' (1); but the following examples can be dubbed 'autobiography beyond functionality'. In the first one, Feldman Barrett simply defines her own socio-cultural background and of course how it can influence who she is and how she thinks as her "perceptions are influenced by the fact [she is] a woman, a mother, an atheist who is culturally Jewish, and a rather pale person living in a country that once enslaved people for having more melanin in their skin than [she does]' (33). The other examples are (very) personal anecdotes that are either about her daughter or her husband. When her daughter was three years old, she spotted a man in a mall with his hair in dreadlocks. The author explains that, at the time, her daughter knew only three people with dreadlocks, one of them being her beloved Uncle Kevin. Feldman Barrett describes how the child's brain 'was furiously launching multiple, competing predictions that could potentially become her experience'. This process amounted to a 'population of 174 predictions' that eventually led Sophia to leap out of her stroller and wrap 'her little arms around the man's leg, shouting, "Uncle KEVIN!" Unfortunately, her prediction was wrong as her uncle was six hundred miles away: 'She looked up into a total stranger's face and shrieked' (117). In my last example, the author relates a very personal fact about her husband: 'My husband, Dan, went through a brief, difficult time a few decades ago before we know each other, and was referred to a psychiatrist' (194). Again, all these passages, ranging from anecdotes to more intimate confessions, could have been left out, but the author decided to include them for rhetorical reasons, but also for unexpected autobiographical aspirations. 


\section{WORKS CITED}

“'Brainy Backlist” Helps Boost Non-Fiction Market.' The Bookseller, June 2018, doi: https:// www.thebookseller.com/news/brainy-backlist-helps-boost-non-fiction-market-795606. Date accessed: 21 July 2019.

'Brilliant and Brainy Books to Take to the Beach This Summer.' Time, May 2015, doi: https:// time.com/3891653/book-summer-reading-list/. Date accessed: 2 September 2019.

De M'Uzan, Michel. Aux confins de l'identité. Paris: Gallimard, 2005.

Dolan, Paul. Happiness by Design. London: Penguin Books, 2014.

Feldman Barrett, Lisa. How Emotions Are Made. The Secret Life of the Brain. London: Pan Books, 2018.

Fludernik, Monika. Towards a 'Natural' Narratology. London: Routledge, 1996.

Fox, Killian and Poppy Noor. 'Best "Brainy" Books of this Decade.' The Observer, July 2018, doi: https://www.theguardian.com/books/2018/jul/29/10-best-brainy-books-last-decade. Date accessed: 2 May 2019.

Galambos, Robert and Daniel E. Sheer. 'A Big Brawny Brainy Book from Texas.' Contemporary Psychology 7:10 (1962) 361-364.

Gilmore, Leigh. The Limits of Autobiography: Trauma and Testimony. Ithaca: Cornell UP, 2001.

Graham, Lesley. 'Scientific Autobiography: Some Characteristics of the Genre.' ASp, 43-44 (2004), Online since 17 March 2010, doi: http://journals.openedition.org/asp/1039. Date accessed: 3 May 2019.

Jurdant, Baudoin. 'Popularization of Science as the Autobiography of Science.' Public Understanding of Science 2:4 (1993) 365-373.

Kahneman, Daniel. Thinking, Fast and Slow. London: Penguin Books, 2011.

Myers, Greg. 'Making a Discovery: Narratives of Split Genes.' In: Christopher Nash and Paul Kegan (eds.), Narrative in Culture. London: Routledge, 1990, 102-126.

Myers, Greg. Writing Biology: Texts in the Social Construction of Scientific Knowledge. Madison: The University of Wisconsin Press, 1990.

Myers, Greg. 'Stories and Styles in Two Molecular Biology Review Articles.' In: Charles Bazerman and James Paradis (eds.), Textual Dynamics of the Professions: Historical and Contemporary Studies of Writing in Professional Communities. Madison: The University of Wisconsin Press, 1991, 45-75.

Phelan, James. Narrative as Rhetoric. Technique, Audiences, Ethics, Ideology. Columbus: Ohio University Press, 1996.

Preston, Alex. 'How the "Brainy” Book Became a Publishing Phenomenon.' The Observer, July 2018, doi: https://www.theguardian.com/books/2018/jul/29/why-brainy-bookbecame-publishing-phenonmenon. Date accessed: 5 May 2019.

Rousseau-Dujardin, Jacqueline. 'Roman familial, écrits autobiographiques et insertion dans le temps.' In: Jean-François Chiantaretto (ed.), Écriture de Soi et Psychanalyse. Paris: L'Harmattan, 1996, 235-248.

Tivnan, Tom. 'Janklow \& Nesbit Reaps the Rewards of Investing in "Smart Non-Fiction".' The Bookseller, November 2018, doi: https://www.thebookseller.com/insight/janklow-nesbitreaps-rewards-investing-smart-non-fiction-885161. Date accessed: 15 July 2019.

Varghese, Susheela Abraham and Sunita Anne Abraham. 'Book-Length Scholarly Essays as a Hybrid Genre in Science.' Written Communication 21:2 (2004) 201-231.

Watson, James D. The Double Helix. A Personal Account of the Discovery of the Structure of DNA. London: Penguin, 1968.

Williams, S. Zainab. 'On the Rise of Brainy Books, and the Best Brainy Books of This Decade: Critical Linking.' Bookriot, August 2018, doi: https://bookriot.com/2018/08/01/ on-the-rise-of-brainy-books-and-the-best-brainy-books-of-this-decade-critical-linkingaugust-1/. Date accessed: 7 July 2019. 
Woolgar, Steve. 'Discovery, logic and sequence in a scientific text.' In: W.R. Knorr, R. Krohn, Richard P. Whitley (eds.), The Social Process of Scientific Investigation. Dordrecht: D. Riedel, 1980, 239-268.

\section{ABOUT THE AUTHOR}

Arnaud Schmitt is a professor at the University of Bordeaux. His field of research is American literature and he has also worked extensively on the concepts of 'autofiction' and 'self-narration'. He has recently published a new book entitled The Phenomenology of Autobiography: Making it Real (Routledge, 2017) and is the corecipient (with Stefan Kjerkegaard, Aarhus University) of the 2016 Hogan Prize for an outstanding essay published in a volume of $a / b$ : Auto/Biography Studies. He was awarded a CNRS scholarship for the academic year 2019-20 and is currently working on a new monograph on photographers who wrote memoirs.

\section{NOTE}

1 Or, for a longer version of Phelan's definition of narrative as rhetoric: 'As many readers will have already recognized, my approach is indebted to rhetorical theorists such as Kenneth Burke and Wayne C. Booth who also emphasize narrative as a distinctive and powerful means for an author to communicate knowledge, feelings, values, and beliefs to an audience: indeed, viewing narrative as having the purpose of communicating knowledge, feelings, values, and beliefs is viewing narrative as rhetoric' (18). 